\title{
圧縮下にある高分子材料測定のための $\mathrm{X}$ 線カメラの試作 ${ }^{*}$
}

\author{
伊 藤 泰 輔** 吉 武 春 男**

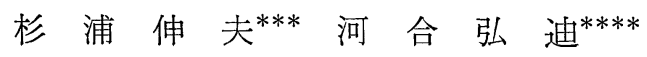

\begin{abstract}
An X-Ray Camera for Studies on Crystalline High-Polymeric
Materials under Compression
\end{abstract}

by

\author{
Taisuke Ito, Haruo Yoshitake, \\ (Faculty of Industrial Arts, Kyoto Technical University, Kyoto) \\ Nobuo Sugiura and Hiromichi KawaI \\ (Faculty of Engineering, Kyoto University, Kyoto)
}

\begin{abstract}
A compression X-ray camera is described in the present paper, devised for obtaining an X-ray photograph by transmission technique for the crystalline high-polymeric materials under uniaxial compression up to $2000 \mathrm{~kg} / \mathrm{cm}^{2}$. The compression is applied by a press screwed by a manual worm-gearing which are set on the camera. The compressive force can be measured by a special gauge placed in the camera in series under the sample holder, and it can be kept constant, when desired for the stress constant experiments, by driving the press during the exposure to compensate the ralaxed stress of the sample.

A technique for an accurate measurement of the small radial shift of the diffraction peak induced by the compressive stress is also described where a flat film cassette equipped with a special metal shield which permits exposure of $2^{\circ}$ section of the film is used. The shift was measured by a direct comparison of the shifted peak under a microscope with the peak obtained under no applied stress and registered, by the use of the metal shield, on the same film in the immediate neighbor of the shifted peak.

(Received Aug. 14, 1968)
\end{abstract}

\section{1 緒言}

桜田らは，種々の型の結晶性高分子について静的引 張応力に対する結晶格子面間隔のひずみを測定し, 高 分子結晶弾性率に関する一連の報告を行なった。

これに対して以下に述べる報告は, 一軸性静的圧縮 応力に対する高分子結晶の力学的特よび結晶学的挙動 を測定するための透過法圧縮X線カメラの試作に関す るものである，このカメラは，定応力測定和よび定ひ ずタ測定の両者に対して可能であり，力計を内蔵し， 得られる一軸圧縮応力の值の上限は, 配向高密度ポリ エチレンを試料とした場合, 約 $2000 \mathrm{~kg} / \mathrm{cm}^{2}$ である.

この值は, 従来多くの報告のみられる金属化合物に 対する高圧X線カメラの圧縮または静水圧能力に比較 するとはるかに低い値であるが，高分子結晶の場合， 上述の圧縮応力の值の範团に打いて, 分子鎖間の距離 は充分に測定しらる程度の変化を示す.一方, 結晶の

\footnotetext{
* 原稿受理 昭和 43 年 8 月 14 日

** 京都工芸㵶維大学工芸学部 京都市左京区松ヶ崎

*** 京都大学工学部 京都市左京区吉田本町

**** 正 会 員 京都大学工学部 京都市左京区吉田本町
}

回転, 相転移などの結晶学的に興味ある種々の現象む 同時に観察される.

\section{2 圧縮 $\mathbf{X}$ 線カメラ}

\section{$2 \cdot 1$ カメラ本体の構造}

Fig. 1 に試作した压縮X線カメラ本体の断面略図を 示す. 以下の説明に明らかなよらに, 圧縮応力は squeeze 方式により得ている。まず，カメラの外郭は主 シリンダ(1)と副シリンダ(2)とから成り, 両者は分離で きる、図ではそれらがロック・ナット(10により固定さ れている、試料ホルダは(7)である. 試料ホルダは後述 のと和り 4 種製作したが，Fig. 1 に示したものはそれ らのららの A型で, これは直射X線ビーム括よ゙回折 X線の通過する頂角 $80^{\circ}$ の円すい孔を両側に有する直 径 $19 \mathrm{~mm}$, 高さ $27 \mathrm{~mm}$ の円柱の中心軸に沿い, 幅 $2 \mathrm{~mm}$, 長さ $19 \mathrm{~mm}$ (円柱直径), 深さ $12 \mathrm{~mm}$ の平ら な底を有するみぞを精密に切ったものである。円すい 孔の軸は溝壁に対し垂直で, 㩐壁に接する部分の円す い孔の直径は $3.5 \mathrm{~mm}$ である。このみぞに, 幅 1.95 $\pm 0.02 \mathrm{~mm}$, 長さ $17 \mathrm{~mm}$, 高さ $4 \sim 5 \mathrm{~mm}$ の大きさ の高分子試料(8)を入れる. 角ねじ(3)の回転による進み 


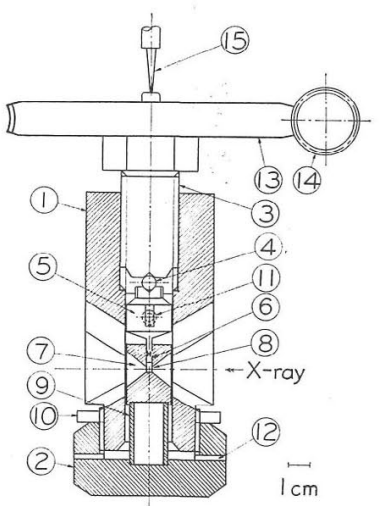

Fig. 1. Cross section of compression X-ray camera.

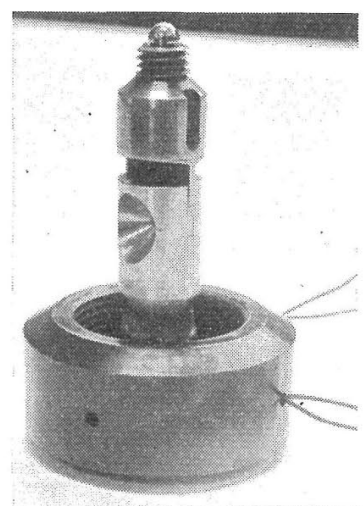

Fig. 2. Photograph showing part of the constitution in the main cylinder of the camera.

が，ボール・ベアリング球(4)，压縮力主伝達子(5)，同 副伝達子(6)を介乙て試料(8) に伝達され, 試料は圧縮力 副伝達子と試料ホルダのみ発の底面との間で圧縮され

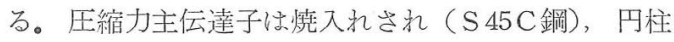
部と舌の部分とから成る、円柱部は主シリンダの内面 に接し，またとの側面には，角礼じの回転に伴ら回転 を止めるつめに対する久㢳を有する (Fig. 2). 圧縮力 主伝達子の舌の部分は試料ホルダの久どにはまるが， したと溝壁との間にはやや遊びをもたせて岁る。これ に対し副伝達子は, 試料ホルダの溝壁との密着和よび すべりが特に良好なよらに製作されている。これらの 部品(4)，(5)，(6)，(7)，(9)上，後述の力計(9)叔よび副シ リンダとの配置を.Fig. 2 に示した.

次に圧縮力は次の上うにして求める。すなわち, 試 料ホルダに対して直列に置いたシリンダ(9)の外壁に 4 枚のひずみゲージ（共和電業 $\mathrm{KK}$ K製，KP-3-A1，ゲ ージ抵抗 $120 \Omega$ ，ゲージ率1.88）を接着してブリッジ 回路を構成し，これを共和電業KK製 PM $5 \mathrm{~L}$ 型ひず 文計に結合してンリンダのひずみを検出し，ひずみに 対心する力を，後述の別に作成した力ーひずみ図から 得る。

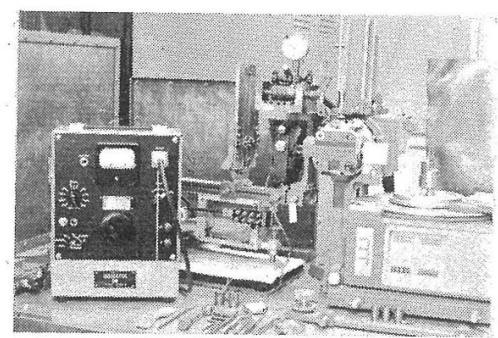

Fig. 3. Photograph of compression X-ray camera in operation.

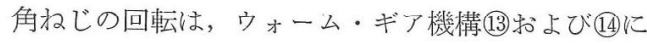
よる、ウォーム・悋じ团の回転はマ二ニアル回転で市 る. 定応力測定に和外定応力の維持は, 測定中に起 こる高分子試料の応力緩和を, ウォーム・秝じの微小 マニュアル回転によって相殺することにより得ること ができる。この回転を自動化することは, 回転に要す るエネルギおよび自動化装置の規模の点などから, 現 在のところ考虑していない。ウォーム・稀じは主シリ ンダに固定された厚さ $15 \mathrm{~mm}$ のたなの上に固定され ているので, 上述の定応力維持は, カメラ〜オプチカ ル・ベンチ〜コリメータの光学系を狂わせることなし に円滑に行ならことができる。試料の圧縮ひずみは， 1/1000 mm ダイヤル・ゲージ15に上り角水じの恋位 を測定することによって得ている。このダイヤル・ゲ 一ジは, ウォーム・䃿じの固定された同じたなの上に 固定されている。カメラの材質は $\mathrm{S} 45 \mathrm{C}$ 鋼である。

Fig. 3 は実測中の試作した圧縮X線カメラ定示す。 使用X線発生装惪は, 理学電機 $\mathrm{KK}$ 製 D-8C型である。 管電圧 $40 \mathrm{kV}$, 管電流 $18 \mathrm{~mA}$, ニッケルはくろ過に より得られる $\mathrm{CuK} \alpha$ 線を, $0.5 \mathrm{mm \phi}$ のペンシル型 コリメータとよりコリメートして使用している。

\section{$2 \cdot 2$ 試料ホルダ}

試料の一軸圧縮とX線回折像の撮影とを理想条件下 に両立させることは簡単ではない. Jamieson ら苟る いは Piermarini ら゙は，ダイヤモンド対抗アンビル間 で試料を压縮し，X線をアンビル内部を透過させて試 料に入射している。筆者らは, Fig. 4 亿示すような 4 種の試料ホルダを試作した。図に見られると㧍り，こ 水らの試料ホルダは，いず䃼も基本的には，平らな底 を有する幅 $2 \mathrm{~mm}$ の反どと，直射小上び回折X線ビ 一ム通過孔または通過みぞとから成る。試料ホルダ $\mathrm{A}$

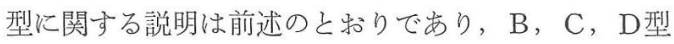
に特いては, X線ビームを通過させるために，A型に 特ける円すい孔の代的りに，試料み矢に垂直な幅 10 $\mathrm{mm}$ (B型) または $3 \mathrm{~mm}$ (C型およびD型) の山型 のみ発が切られている。压縮応力は一軸性であり, 試 料の上面と底面とを除く側面のらち，㩐壁に対问する 部分以外は外界に詨して open である。 

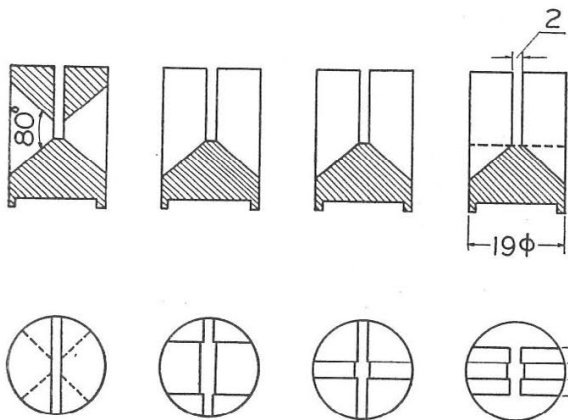

Type A
TypeB

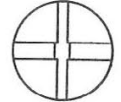

Type C

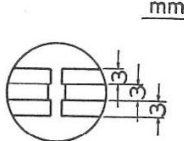

Type D
Fig. 4. Four types of the sample holders. Vertical cross sections (Above) and upper views (Below).

これらの試料ホルダを使用した場合, 高い圧縮応力 の領域に拈いて, 理想状態からの背反が次の 2 点で起 こる。(1)試料と透過ビームより上側の試料ホルダ溝壁 之の間の摩擦力による力の損失. (2)高分子材料の圧縮 変形和よびフロー変形に上る压縮応力の一軸性の消失。 (1)以関しては, 試料と算壁との間の接触面積学小さく するように試料ホルダを設計することが肝要で，試料 ホルダ $\mathrm{B}$ 型怙よび $\mathrm{D}$ 型に沶いてはこの点に注意した。 また，試料との相互作用のない潤滑油夌满壁に用いる ことも有効で屍る。次に(2)に関しては，入射X線ビー ムに 垂直方向にみた試料の断面が，ビーム断面 $(0.5$ $\mathrm{mm} \phi)$ に比べて充分に大きな寸法を有するから，入射 X線ビームと圧縮軸とに垂直方向の試料の変形は(2)の 点に関し無視してさしつか党なく, これに対し入射X 線ビーム方向に起こる試料の変形が好ましくない問題 色提起する。こ机は不可避の問題で㐫り，变形量 $10 \%$ $(0.2 \mathrm{~mm})$ 程度までは，(2)の観点上り久たときの近似 的な測定として実駼が許容されよう。すなわち，この ことが，試作した圧縮X線カメラの圧縮応力の値の上 限を自ら限定する結果となる。したがって，試料の結 晶化度をできるだけ高め，また薄いフィルム試料を重 ねてフィルム面に垂直に圧縮応力を加光る方法をとる ことなどにより，二次的な意味に执いて，カょラの圧 縮応力の上限の值を大きくすることができる.

\section{$2 \cdot 3$ 力計の力-ひずみ曲線の作成および 圧縮応力 の求め方}

力計(9の力ーひずみ曲線の作成は，前述の PM 5 L 型ひずみ計と，振り子式直接何重方式の $2 \mathrm{t}$ 材料試験 機とを使用して行なった。このとき, 力計単独に対し て測定することを避け，Fig. 5 に示すと叔り，部品(4) -(5)-(6)-(7)-(9)-(2)を実測条件と同じ状態に配置し（た だし部品 (6) の圧縮刀副伝達子は 2 個使用した)，材料 試験機の区縮力をボール・ベアリング球と副ンリンダ 基底面との間で印加した。このよらにして得られた力 計の力ーひずみプロットの直線性はきわめて良好で，

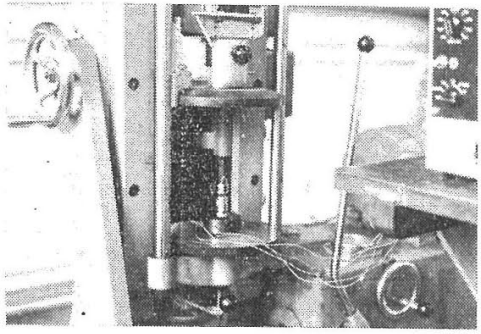

Fig. 5. Calibration for the strain gauge using a 2-ton load tester of pendulum dead weight type.

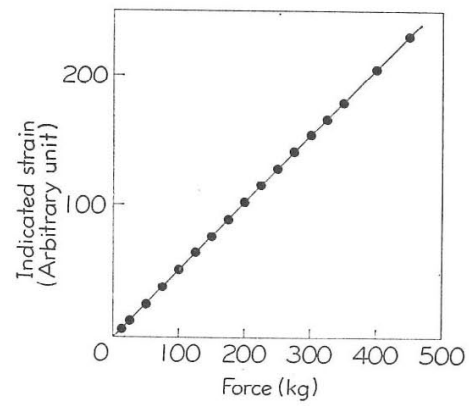

Fig. 6. Indicated strain of the strain gauge as a function of load. The strain is expressed by the instrumental value of the strain indicator where the unity corresponds to a strain of $3 \times 10^{-6}$

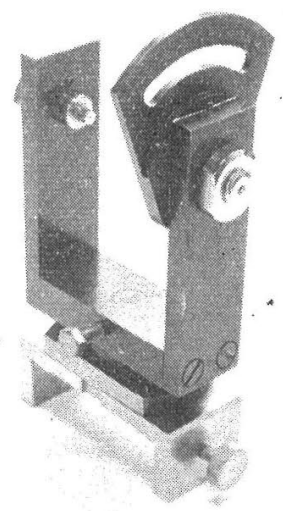

Fig. 7. Mounting device of the camera for optical bench.

るた室温に抢ける再現性も非常に良好でする。 Fig。6 に力計の力ーひずみ図を示した。

次に圧縮応力の値は，まず見掛けの压縮応力 $\sigma_{a} の$ 值が，圧縮力 $F$ を試料の初期断面積 $A_{0}$ で除すことに より得られる。次に見掛けの圧縮応力の試料断面積の 变化住対する補正が，圧縮ひずみを アソン比を岒て， $\sigma_{a} /(1+2 \nu \xi)$ により求められる。

$2 \cdot 4$ カメラ支持台

カメラ本体をオプチカル・ベンチに固定するカメラ 支持台はFig. 7 に示寸と物りである。この支持台は， カメラを主シリンダ中心軸，したがって試料ホルダ中 
心軸回りの任意の位置に固定できる。また，入射X線 ビームとカメラとの関係がちょらど Fig. 1 に示され る位置にあるとき，入射 $\mathrm{X}$ 線ビームと主シリンダ軸と のなす角度を, $90 \pm 40^{\circ}$ の範囲において傾斜させるこ とができる。

$$
3 \text { 測 定 方 法 }
$$

\section{$3 \cdot 1$ 一般的方法}

通常の平面カメラカセットを使用した場合には，透 過 X線写真法に関する通常の実験技術を本報告の圧縮 X線力メラに適用することができる。Fig. 8 は，160 ○に拈いて熱プレス後, プレス間において室温まで徐 冷して得た厚さ $1.95 \mathrm{~mm}$ の高密度ポリエチレン（シ ヨウレックス 6000）無配向フィルムを試料とし， $\sigma_{a}$ $=0$ 和よび $500 \mathrm{~kg} / \mathrm{cm}^{2}$ (定応力) に执いて撮影した X線図である。図から明らかなように， $\sigma_{a}=0$ に㸱い ては無配向の粉末図形が得られるが，図の上下方向に 加えた $\sigma_{a}=500 \mathrm{~kg} / \mathrm{cm}^{2}$ の圧縮応力により, 各結晶格 子面の配向和よび斜方晶から単斜晶への相転移の起こ ることがわかる。

高分子X線回折に拈いては，入射X線ビームと結晶 の繊維軸（分子鎖軸）との間の角度の関係が特に重要 である。試料として延伸配向フィルムを使用し，これ
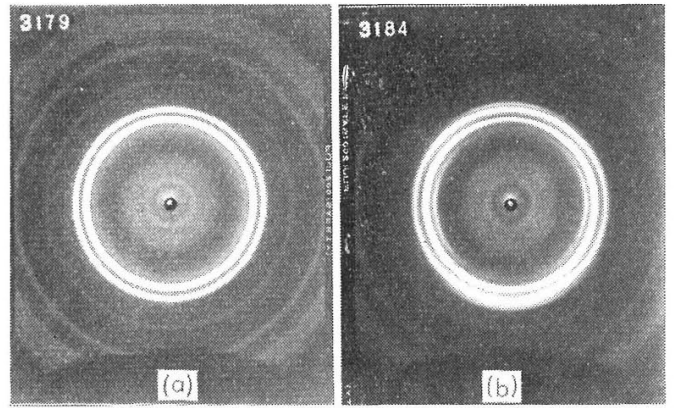

(a) Unoriented annealed film under no applied stress, (b) The same sample as subjected to a constant compressive stress of $500 \mathrm{~kg} / \mathrm{cm}^{2}$. Stress direction vertical. Both were obtained by using nickel-filtered copper radiation $(40 \mathrm{kV}, 18$ $\mathrm{mA}$ ) under film exposure of $20 \mathrm{~min}$.

Fig. 8. X-ray diffraction patterns of high density polyethylene.
からたんざく型試料片を切り取りこれを試料ホルダ のみぞに積重ねて使用すれば，压縮軸，入射X線の方 向および繊維軸(延伸方向)の間の主要な関係を Fig. 9 (a)，(b)に示すように選ぶことができる。図の(c)の配置 に拈いては単結晶累積膜を使用するが，この場合には 繊維軸はフィルム面に対し重直である。

$3 \cdot 2$ 特殊平面フィルムカセットの製作および測定 方法

区縮応力による結晶格子面間隔の圧縮ひずみを測定 するには，圧縮応力による反射ピークの半径方向 $(2 \theta$ 方向）の微細なシフト（変位）在測定しなければなら ない、この目的のために，Fig. 10 に示すよらに，入 射X線ビームの直射点を中心として回転し, カセット の黒紙にらょらど接する開角 $2^{\circ}$ の微細な扇形スリッ 卜を有する平面カメラカセット製作した。使用する X線フィルムの大きさは， $4.3 \mathrm{~cm} \times 10 \mathrm{~cm}$ あるいは $4.3 \mathrm{~cm} \times 20 \mathrm{~cm}$ である。この特殊カセットを使用した 測定方法は次のと扬りである。

まずデバイ・シェラ図の撮影においては，圧縮 応力印加前, 応力下就よび応力除去後の 3 時点 $t_{1}$, $t_{2}, t_{3}$ に和いて，あるいは，要するに試料ホルダに七 ットした同じ試料に関し，任意の応力条件拈よび履歴

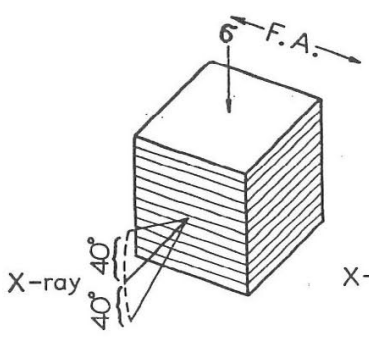

(a)

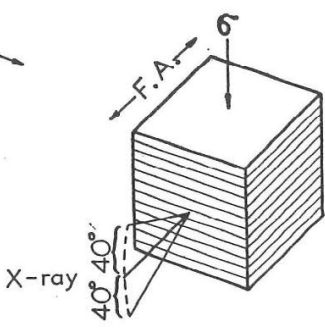

(b)

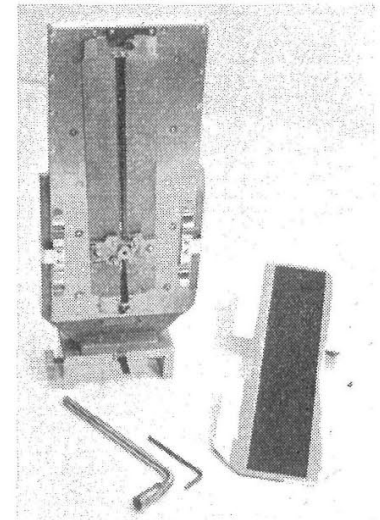

Fig. 10. Flat film cassette equipped with a special metal shield which permits exposure of $2^{\circ} \mathrm{sec}$ tion of the film.

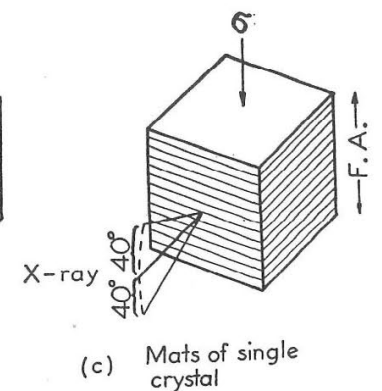

Fig. 9. Three major experimental arrangements for the incident X-ray beam, fiber axis (F. A.) of the oriented sample and the compressive stress $(\sigma)$. 
条件に执いて選んだ 3 個の時点 $t_{1}, t_{2}, t_{3}$ に沶いて， 扇形スリットの操作により，それぞれ 1 回ずつ，乙か 心開角 $2^{\circ}$ の扇形露光带是互いに充分接近さ呕て露出 る行なら。上述の 繊維図の赤道または子午線の撮影に执いては，2個の 時点 $t_{1}, t_{2}$ に扣いて, 扇形露光帯が，反射スポットの 半径方向中心軸を境として，ちょうど対称の位置にあ るように互いに接近させて露出を行なら。このよらに して撮影されたX線写真ネガは Fig. 11 に示すように 得られる。すなわら, 同じ試料の種々の力学的条件下 での反射ピークの位置を，1枚のX線写真ネガ上にお いて，互いに直接に，秀た多くの格子面に関して同時 に比較することができる。 また入射X線ビーム像を適 当な濃度でネガ上に記録できる。したがって，ての位 置より, 反射線（またはスポット）までの距離を測定 し, 常法に従って区射格子面の面間隔あるいはカメラ 距離を決定することができる。

次に，Fig. 11 のネガを用いた反射ピークのシフト に対する測定を以下のよらに行なった。すなわち， Fig. 11 において，特定の反射ピークに関するそれぞ れ異なる応力条件で得られた 2 個(繊維図)または 3 個（デバイ・シェラ図）のX線反射像の全体を, 顕微 鏡下に $35 \mathrm{~mm}$ カメラにより10倍に拡大撮影した。こ れをさらに引伸機により手札の大きさの印画紙上に転 写し，顕微鏡視野内に設子たスケールを基礎に，印画 紙上に扣いて反射ピークのシフト走測定した。顕微鏡 写真撮影装置はオリンパス PM-6 を，また引伸機は

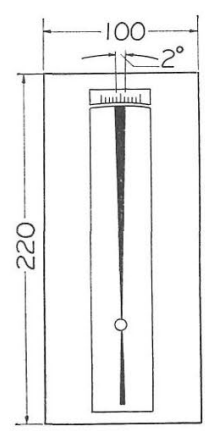

$\mathrm{mm}$

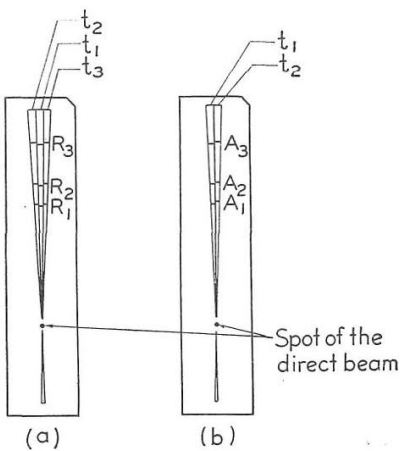

Fig. 11. Schematic diagram of (a) powder patterns and $t_{3}$ and (b) equatorial (Or meridional) fiber patterns obtained by exposure at times $t_{1}$ and $t_{2}$. The metal shield is rotated after each exposure.

*1 各格子面は一般に圧縮応力べクトルに対して傾斜しているから, 垂直応力に対する補正を考虑する必要がある.

*2 Fig. 11 の線ビーム直射点の上下両側の扇形露光帯において, 高密度ポリエチレンの蘚鋭な 200 反射（デバイ・シェラ図）走利 用して, ネガフィルムの入射X線ビームに刘する垂直性を検討し, $90_{-0.0^{\circ}}^{+0.2^{\circ}}$ の良好な結果圶得た。
フジ引伸機 $\mathrm{B}$ 型を使用した。視野内スケールの 1 目盛 の絶対長さは, 島津 $0.01 \mathrm{~mm}$ 対物ミクロメー夕を使 用して常法により決定した。

上述の測定結果の例を Fig. 12 以下に示す. Fig. 12 に使用した試料は, $90^{\circ} \mathrm{C}$ 空気浴中で10倍に熱延伸後, $120^{\circ} \mathrm{C}$ に招いて熱固定した厚さ $0.2 \sim 0.3 \mathrm{~mm}$ の高密 度ポリエチレン（ショウレックス6000）配向フィル ムである。この試料から所定の大ささ（延伸方向 9.0 $\mathrm{mm}$, 直角方向 $1.95 \pm 0.02 \mathrm{~mm}$ ) のたんざく型フィル ムを切り取り,これを約 20 枚重ねて試料ホルダ $\mathrm{D}$ 型に セットし, Fig. 9 の配置(a)により, カィラ距離 $10 \mathrm{~cm}$, 露出時間 6 分, $\sigma_{a}=500 \mathrm{~kg} / \mathrm{cm}^{2}$ の定応力比し, $t_{1}=$ 応力印加前約 10 分, $t_{2}=$ 応力印加後 3 分之して撮影し た。Fig. 12 の各ネガに打いて，上下方向が厈縮方向 に相当し, また左側の露光带が $t_{1}$ に, 右側の露光带 が $t_{2}$ に対応し, 図に見ら机る強い赤道反射は, 広角 側 (上側) が 200, 内角側 (下側) が 110の各反射で 㐫る。 3202 番のネガは， 3201 番に対する露出終了後， カメラを $180^{\circ}$ 水平回転し, 人射X線ビームの当る試 料の側面を反対側とし, その他の条件を同じにして得 られた結果である。Fig. 13 祘よび 14 は, 広伤側の 200反射像の前述の測定方法に従う拡大図であり，各 図に招いて, 下側が直射ビーム側, また右側の露光带 が $t_{1}$ に, 左側の露光帯が $t_{2}$ に対応する。刻印されて いるスケールの 1 目盛は絶対長さで $0.0781 \mathrm{~mm}$ に相 当する。

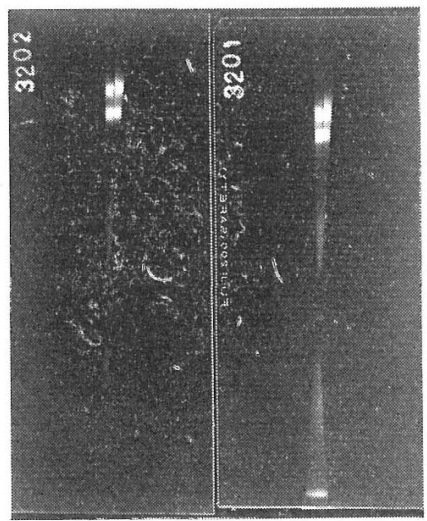

Right film:Before (Left section) and after (Right section) application of a constant compressive stress of $500 \mathrm{~kg} / \mathrm{cm}^{2}$, obtained by exposure of $6 \mathrm{~min}$ for each section. Left film: The same as for the right film with the exception of the incident $\mathrm{X}$-ray beam being impinged on the opposite side with respect to the same sample which was attained by a horizontal 180 degrees rotation of the camera.

Fig. 12. Equatorial fiber patterns of high density polyethylene drawn film obtained by using the special film cassette under the experimental arrangement (a) illustrated in Fig. 9. Stress direction vertical. 110 (In lower angles) and 200 (In wider angles) reflections are seen. 


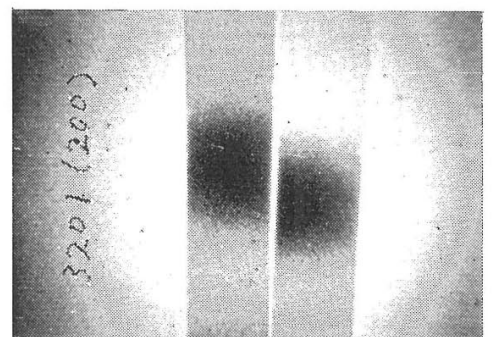

Fig. 13. Magnified photograph under microscope of the part of the 200 reflections registered on the film No. 3201, the right and left sections being exchanged in position. One graduation of the scale corresponds to $0.0781 \mathrm{~mm}$. The radial shift of the 200 peak induced by the compressive stress $\left(\sigma_{a}=500 \mathrm{~kg} / \mathrm{cm}^{2}\right)$ was measured to be $+0.633 \mathrm{~mm}$.

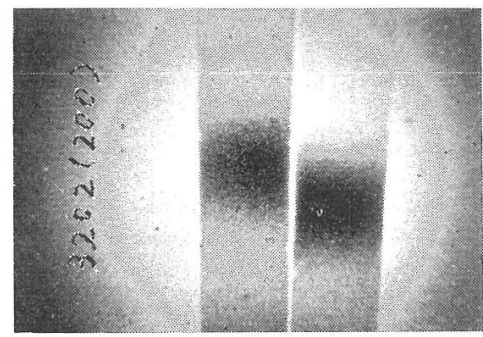

Fig. 14. Magnified photograph of the part of the 200 reflections in the film No. 3202. The measured radial shift of the 200 peak was $+0.625 \mathrm{~mm}$ which is in good accordance with the result obtained in Fig. 13, showing no buckling of the sample under compression.

Fig. 13 和よび 14 に执いて, 白色の金属細線を張 ったワクを使用して, 各ピークの反射濃度の中心位置 を，他の側の露光帯を和扣いながら刻印スケールに基
づいて読み取り, 数回の読取り值の平均值を求め, そ れらの差をもって区射ピークのシフト $(d r)$ とした。

Fig. 13 おょび 14 の測定例では，dr の測定誤差幅は $0.05 \mathrm{~mm}$ (0.6目盛)であった。以上の結果，Fig. 13 の200反射に対して $d r=+0.63 \mathrm{~mm}(+8.0$ 目盛 $)$ が， Fig. 14 の200反射に対して $d r=+0.63 \mathrm{~mm}(+7.9$ 目 盛）が得られ，両者の $d r$ 值はよく一致した。したが って, 圧縮による試料の坐屈がなんら起こっていない ことが同時に証明された。

終わりに本研究にあたり，ご指導いただいた同志社 大学工学部桜田一郎教授に深謝する。 カメラの製作を ご援助いたたいた京都工芸繊維大学工芸学部岡本隆教 授，富岡技官，材料試験機の使用を許可された同福田 正成教授, また, 本研究を通じ終始ご激励とご援助を いただいた同増尾富土雄教授に厚く感謝する。

(昭和 43 年 6 月 29 日 高分子研究発表会, 昭和 43 年 7 月 18 日 第 7 回 X 線材料強度に関するシンポジウムにて講演）

\section{参 考 文 献}

1）たと光ば Sakurada, I., T.Ito, and K. Nakamae, J. Polymer Sci., Part C, 15, 75 (1966).

2）文献 3）および 4) 飞もみられるとおり，乙れらの高圧 X線力メラの多くは 20 30 kbar，すなわち 20 30 t/ $\mathrm{cm}^{2}$ の圧縮能力を有する。皇た，100kbar の高圧X線 回折装置が Hall らおよよび Jamieson らにより報告され ている: Barnett, J. D., and H. T. Hall, Rev. Sci. Instr., 35, 175 (1964); Jamieson, J. C., and A.W. Lawson, J. Appl. Phys., 33, 776 (1962).

3) Jamieson, J.C., A.W. Lawson, and N.D. Nachtrieb, Rev. Sci. Instr., 30, 1016 (1959).

4) Piermarini, G. J., and C.E. Weir, J. Research Nat1. Bur. Standards, 66 A, 325 (1962). 